\title{
Corticosteroid-induced Knee Osteonecrosis and Accompanying Femoral Head Osteonecrosis
}

\author{
Kortikosteroid Kaynaklı Diz Osteonekrozu ve Eșlik Eden Femur Başı Osteonekrozu
}

\author{
(D) Nuran Sabir, (D) Furkan Ufuk \\ Pamukkale University Faculty of Medicine, Department of Radiology, Denizli, Turkey
}

\begin{abstract}
Introduction: The aim of this study was to investigate the prevalence and magnetic resonance imaging (MRI) findings of knee osteonecrosis (ON) in patients with arthralgia who received corticosteroid therapy. We also aimed to demonstrate the diagnostic performance of plain radiography in knee ON when MRI is accepted as the gold standard and to investigate the prevalence of accompanying femoral head $\mathrm{ON}$ in patients who underwent hip MRI.

Methods: One hundred and sixty-two knee X-rays and MRI examinations of 136 patients with knee pain and a history of corticosteroid intake were retrospectively evaluated for the presence of $\mathrm{ON}$. Localization, maximum size of dominant lesion, multiplicity of lesions, presence of bone edema, double-line sign and subchondral extension were evaluated in patients with ON. Accompanying femoral head ON was also investigated in patients who underwent hip MRI.

Results: MRI revealed ON in 37 knees of 28 patients. The sensitivity and specificity of plain radiography in the diagnosis of knee joint ON was $29.73 \%$ and $98.40 \%$, respectively. There were multiple lesions in 31 knees and subchondral space was affected in 24 knees. The double-line sign and bone marrow edema were present in most of the lesions. Of the 28 patients with knee ON, only 16 had hip joint MRI and five of these patients (31.3\%) had femoral head $\mathrm{ON}$.

Conclusion: Plain radiography has low sensitivity but high specificity for the diagnosis of knee ON. Corticosteroid-induced $\mathrm{ON}$ tends to be multifocal, and a significant proportion of patients with knee ON during corticosteroid therapy have ON of the hip joint.
\end{abstract}

Keywords: Magnetic resonance imaging, plain radiography, osteonecrosis, corticosteroid, knee, hip
öZ

Amaç: Bu çalışmadaki amacımız kortikosteroid tedavisi alan ve artralji şikayeti olan hastalarda diz ON'nin (ON) manyetik rezonans görüntüleme (MRG) ile prevalansını ve görüntüleme bulgularını araştırmaktır. Ayrıca MRG altın standart olarak kabul edildiğinde diz ON'de düz radyografinin tanısal performansını göstermeyi ve bu hastalarda eșlik eden femur başı ON'nin prevalansını araștırmayı amaçladık.

Yöntemler: Kortikosteroid alımı öyküsü ve diz ağrısı olan 136 hastaya ait 162 diz grafisi ve MRG tetkiki ON varlığı açısından retrospektif olarak değerlendirildi. ON'si olan hastalarda lokalizasyon, maksimum dominant lezyon boyutu, lezyonun çokluğu, kemik ödemi varlığı, çift hat işareti ve subkondral tutulum değerlendirildi. Kalça MRG uygulanan hastalarda eșlik eden femur başı ON'si de araştırıldı.

Bulgular: MRG'de 28 hastaya ait 37 dizde ON vardı. Diz eklemi ON tanısında düz grafinin duyarlılık ve özgüllügüu sırasıyla $\% 29,73$ ve $\% 98,40$ idi. Otuz bir dizde çok sayıda lezyon vardı ve 24 dizde subkondral boșluk etkilenmekteydi. Lezyonların çoğunda çift çizgi ișareti ve kemik iliği ödemi mevcuttu. Diz ON'si olan 28 hastanın sadece 16'sında kalça eklemi MRG yapılmıştı ve bu hastaların 5'inde $(\% 31,3)$ femur başı ON'si vardı.

Sonuç: Düz radyografi diz ON tanısı için düșük duyarlılığa ve yüksek özgüllüğe sahiptir. Kortikosteroid kaynaklı ON çok odaklı olma eğilimindedir ve kortikosteroid tedavisi sırasında diz ON'si olan hastaların önemli bir kısmında kalça eklemi ON'si vardır.

Anahtar Kelimeler: Manyetik rezonans görüntüleme, düz radyografi, osteonekroz, kortikosteroid, diz, kalça
Address for Correspondence/Yazıșma Adresi: Furkan Ufuk MD, Pamukkale University Faculty of Medicine, Department of Radiology, Denizli, Turkey

Phone: +90 5545115088 E-mail: furkan.ufuk@hotmail.com ORCID ID: orcid.org/0000-0002-8614-5387

Cite this article as/Atıf: Sabir N, Ufuk F. Corticosteroid-induced Knee Osteonecrosis and Accompanying Femoral Head Osteonecrosis. İstanbul Med J 2019; 20(4): 306-11.
Received/Geliș Tarihi: 14.01.2019 Accepted/Kabul Tarihi: 13.03.2019

(c) Copyright 2019 by the Istanbul Training and Research Hospital/Istanbul Medical Journal published by Galenos Publishing House.

(C) Telif Hakkı 2019 Istanbul Ĕgitim ve Araștırma Hastanesi/Istanbul Tıp Dergisi, Galenos Yayınevi tarafından basılmıștır. 


\section{Introduction}

Osteonecrosis (ON), also known as avascular necrosis of bone, is a disease with unexplained pathogenesis that disrupts joint structure and causes progressive dysfunction (1). Early recognition of ON is very important in terms of protection of joints (2). The most common symptom of $\mathrm{ON}$ is pain that is exacerbated by exercise. ON has many causes and corticosteroid (CS) intake is one of the most important causes (1-3). The relationship between CS dose and ON is contradictory. Although many authors claim that the cumulative CS dose is the most important factor (4-6), others have shown that ON may develop independently of dose $(7,8)$. Vreden et al. (7) showed that even patients receiving CSS at physiological doses for adrenal insufficiency might develop ON. CSinduced $\mathrm{ON}$ is most commonly seen in the femoral head and it may also be seen around the knee, shoulder, elbow, hand and ankle joints. Magnetic resonance imaging (MRI) is the most sensitive and useful method for the early diagnosis of ON $(1,5,9)$. However, there is no consensus on whether asymptomatic patients who are on CS therapy should be screened for ON.

Our aim in this study was to investigate the prevalence and imaging findings of knee ON by MRI in patients who were on CS therapy and complaining of arthralgia. We also aimed to demonstrate the diagnostic performance of plain radiography when the MRI is accepted as the gold standard for detection of knee $\mathrm{ON}$ and to investigate the prevalence of accompanying femoral head ON in patients who underwent hip MRI.

\section{Methods}

This study was approved by institutional Pamukkale Universtiy Ethics Committee (decision no: 60116787-020/8340). Informed consent was waived due to retrospective nature of the study. Patients with a history of knee joint surgery were excluded from the study because they could cause misinterpretation of imaging findings. One hundred and sixtytwo knee MRI examinations and X-rays of 136 patients (102 females, mean age: $39.5 \pm 14.5$ years, range: $16-78$ years) with knee pain and history of CS intake due to various chronic diseases were retrospectively evaluated by two radiologists (with an experience of 3 and 20 years) in consensus for the presence of $\mathrm{ON}$. Anteroposterior and lateral X-rays of all patients were obtained. MR images were obtained using a 1.5 Tesla superconducting magnet (GE Signa Excite HD, GE Medical Systems, Milwaukee, Wisconsin, USA) and a dedicated quad knee coil. Knee joint MRI examinations consisted of a sagittal T1-weighted (T1W) spin echo (SE), sagittal proton density-W fast spin-echo (FSE) with fat suppression (FS), axial proton density-W FSE with FS and coronal T2W FSE with FS. Other MRI parameters are shown in Table 1.

Knee joint X-rays were investigated for the presence of $\mathrm{ON}$ and findings such as sclerotic lesions, focal osteopenia, cortical collapses and subchondral radiolucency consistent with $\mathrm{ON}$ were recorded. The observers were blinded to the clinical information and MRI findings of patients. Then at least 30 days later, knee joint MRI examinations of the patients were evaluated for the presence of ON according to predefined MRI findings (10). Localization, maximum size of the dominant lesion, multiplicity of lesions, presence of bone edema, double-line sign and subchondral extension were evaluated in these patients. Accompanying femoral head ON was also investigated in patients who underwent hip MRI.

\section{Statistical Analysis}

Statistical analysis was performed using SPSS for Windows (Version 24.0, SPSS Inc. IBM Corp, Chicago, IL). Continuous variables were expressed as mean \pm standard deviation and range (minimum-maximum), and categorical variables as number and percentage. Comparison of groups

\section{Table 1. Magnetic resonance imaging parameters}

\begin{tabular}{|c|c|c|c|c|c|c|c|}
\hline & FOV $(\mathrm{cm})$ & Matrix/NEX & $\begin{array}{l}\text { Slice thickness/ } \\
\text { gap (mm) }\end{array}$ & TR (msn) & TE (msn) & ETL & BW \\
\hline Sagittal T1-W SE & 16 & $256 \times 192 / 1$ & $3 / 0.5$ & 600 & 30 & - & 16 \\
\hline Sagittal PD-FSE & 16 & $196 \times 256 / 1$ & $4 / 0.5$ & 4000 & 40 & 8 & 16 \\
\hline Axial PD-FSE & 16 & $196 \times 256 / 1$ & $3 / 0.5$ & 4000 & 40 & 8 & 16 \\
\hline Coronal T2-W FSE & 16 & $196 \times 256 / 1$ & $3 / 0.5$ & 4300 & 40 & 8 & 16 \\
\hline
\end{tabular}

Table 2. Diagnostic performance of plain radiography in the diagnosis of knee joint osteonecrosis (magnetic resonance imaging is accepted as gold standard)

\begin{tabular}{|l|l|l|}
\hline & Value & $\mathbf{9 5 \%} \mathbf{C l}$ \\
\hline Sensitivity & $29.73 \%$ & $15.87 \%$ to $46.98 \%$ \\
\hline Specificity & $98.40 \%$ & $94.34 \%$ to $99.81 \%$ \\
\hline Positive likelihood ratio & 18.58 & 4.31 to 80.12 \\
\hline Negative likelihood ratio & 0.71 & 0.58 to 0.88 \\
\hline Positive predictive value & $84.62 \%$ & $56.06 \%$ to $95.95 \%$ \\
\hline Negative predictive value & $82.55 \%$ & $79.30 \%$ to $85.38 \%$ \\
\hline Accuracy & $82.72 \%$ & $76.00 \%$ to $88.20 \%$ \\
\hline Cl: confidence interval & & \\
\hline
\end{tabular}


with non-normal distribution was performed using Mann-Whitney $U$ test. Independent samples t-test was used for comparisons in normally distributed data. $\mathrm{P}<0.05$ was considered statistically significant.

\section{Results}

Only 13 (9.6\%) knee joint X-rays showed a lesion compatible with ON. However, in a total of 162 knee joint MRI examinations, 37 knees (22.8\%) (21 left and 16 right knees) of 28 patients (20.6\%) (18 female, mean age: 42.8 \pm 13.4 years, range: 16-75 years) had ON. Accepting MRI as gold standard, diagnostic performance of plain radiography for diagnosis of knee ON is shown in Table 2.

MRI revealed multiple lesions in 31 knees $(n=162,19.1 \%)$ and single lesion was found in six knees $(n=162,3.7 \%)$ with ON. Dominant lesions in each knee were evaluated by MRI, and 28 of 37 lesions (75.7\%) had a double-line sign, 33 of 37 knees (89.2\%) had bone marrow edema and the size of dominant lesions ranged from 9 to $98 \mathrm{~mm}$ (mean: $37.7 \pm 19.8$ mm, median: $37 \mathrm{~mm}$ ) (Figure 1-3). The lesions were found to extend to the subchondral space in 24 knees (64.9\%). There was no significant

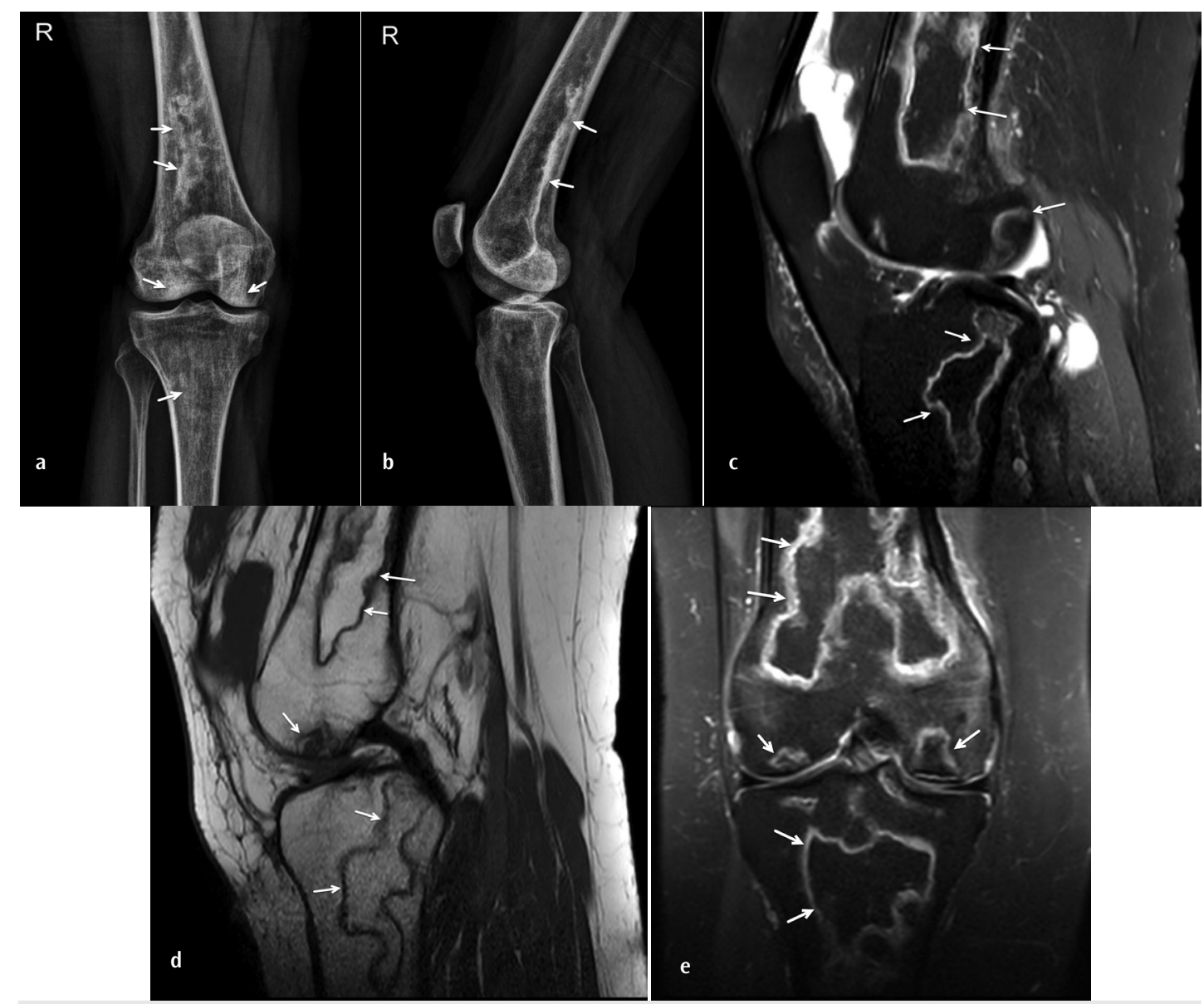

Figure 1 a-e. A 36-year-old female patient with Behçet's disease treated with corticosteroid for 6 years. Anteroposterior (a) and lateral (b) plain X-rays show sclerotic changes (arrows) in both proximal tibia and distal femur without collapse. Sagittal proton density weighted (W)-fast spin-echo (FSE) (c), sagittal T1-W) spin-echo (d) and coronal T2-W FSE (e) images show multifocal serpiginous areas suggesting osteonecrosis around both knees (arrows). The areas have inner hypointense and outer hyperintense rim on T2-W images (double-line sign). Overall features are suggestive of osteonecrosis that also involves the subarticular regionA 32-year-old male patient with retroperitoneal fibrosis treated with corticosteroid for 3 years.

Table 3. Involved sites of osteonecrosis in patients with single lesion and multiple lesions

\begin{tabular}{|l|l|l|}
\hline & Single lesion $(\mathbf{n}=6)$ & Multiple lesions (n=31) \\
\hline Distal femoral diaphysis & $2(33.3 \%)$ & $20(64.5 \%)$ \\
\hline Lateral femoral condyle & $2(33.3 \%)$ & $27(87.1 \%)$ \\
\hline Medial femoral condyle & $1(16.7 \%)$ & $24(77.4 \%)$ \\
\hline Medial tibial plateau & $1(16.7 \%)$ & $10(32.3 \%)$ \\
\hline Lateral tibial plateau & - & $8(25.8 \%)$ \\
\hline Proximal tibial diaphysis & - & $4(12.9 \%)$ \\
\hline All compartments & - & $11(35.5 \%)$ \\
\hline
\end{tabular}


relationship between the number of lesions and the distribution sites $(p=0.452)$. The distribution sites of knee $O N$ in patients with single and multiple lesions are shown in Table 3.

The duration of CS intake was between 1 and 13 years (median: 7 years). The CS doses taken during the course of the disease varied and unfortunately these doses could not be determined. Clinical indications for CS therapy in patients with knee ON are shown in Table 4.

Only 16 out of 28 patients with knee ON had hip joint MRI (57.1\%) who had hip pain. Five of 16 patients (31.3\%) had femoral head ON and four of these five patients (80\%) had ON of both femoral heads.

\section{Discussion}

Our results showed that approximately one third of patients suffering from arthralgia who had knee ON during CS therapy had femoral head ON. CS-induced knee ON was present in approximately one of the five patients with long-term CS intake. Double-line sign and bone marrow edema were the most common MRI findings in CS-induced knee ON. Plain radiography has low sensitivity, but high specificity for the diagnosis of knee joint $\mathrm{ON}$ in patients suffering from arthralgia and receiving CS therapy.

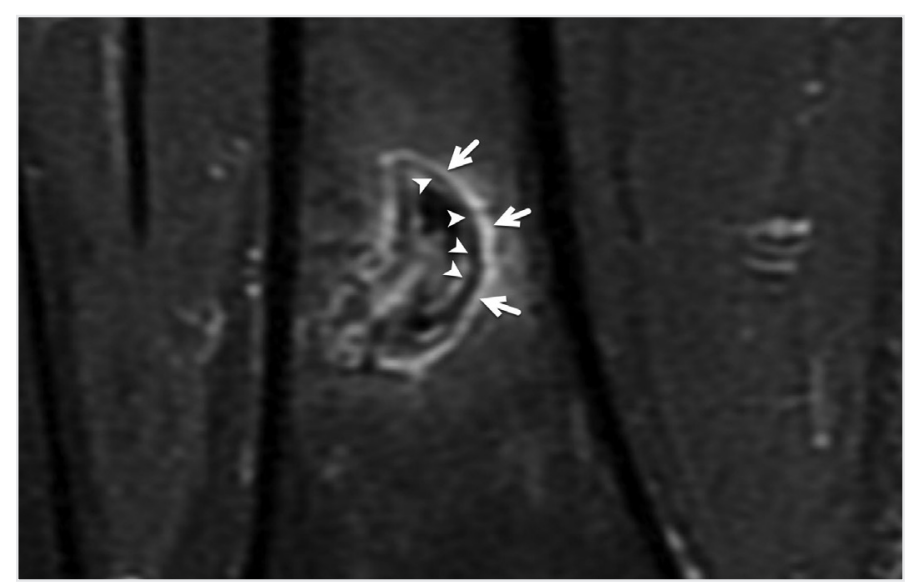

Figure 2. The coronal T2-Weighted fast spin-echo image shows serpiginous area in the distal femoral diaphysis with inner hypointense (arrowheads) and outer hyperintense rim (arrows) (double-line sign)
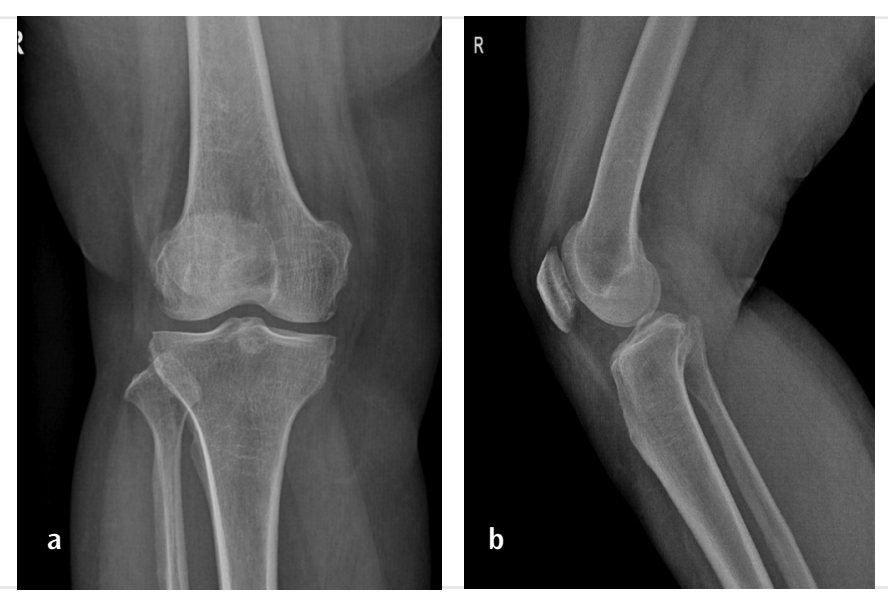

Following hip joint, the knee joint is the second most frequent joint affected by $\mathrm{ON}$. Knee joint involvement will occur in $10 \%$ of patients with hip joint ON (1). Gladman et al. (2) showed that bilateral femoral head ON in $54.7 \%$ of systemic lupus erythematosus (SLE) patients treated with CS, and knee ON in $18.9 \%$ of these patients. However, our study showed that $31.3 \%$ of patients suffering from arthralgia with knee joint ON on CS therapy had hip joint $\mathrm{ON}$. When the results of this study are evaluated together with the findings in the literature, our results support that the femoral head is affected more frequently than the knee in patients on CS therapy.

MRI is considered the gold standard for the diagnosis of ON and it has a very high diagnostic performance $(1,5,9,11)$. Other imaging modalities such as plain radiography, bone scanning, positronemission tomography and computed tomography for the diagnosis of femoral head ON have been previously studied extensively (11-14). Prompt diagnosis and early treatment of $\mathrm{ON}$ is critical because it is associated with a more favorable prognosis $(13,15)$. Previous studies have shown that plain radiography has very low sensitivity for the early period of femoral head ON (10-13). Conklin et al. (16) and Deutsch et al. (17) described that plain radiography has a sensitivity of $41 \%$ and $44 \%$, respectively, for the detection of CS-induced femoral head ON. To the best of our knowledge, there are no studies evaluating the performance of plain radiography in the diagnosis of knee joint $\mathrm{ON}$. We found that the sensitivity of plain radiography for the diagnosis of knee joint $\mathrm{ON}$ was only $29.7 \%$ in patients receiving CS therapy with complaints of arthralgia. However, because of its high specificity (98.4\%), and being cheap and easily accessible, we suggest that plain radiography should be the first choice in knee joint in patients receiving CS therapy, as well as in the hip joint.

CS-induced ON tends to be multifocal lesions at multiple joints, as illustrated by studies of patients with SLE who are on long-term CS therapy $(2,18,19)$. Similarly, we found that five of $16(31.3 \%)$ patients with knee joint ON had femoral head ON who were complaining of hip joint pain. In the presence of multiple joint pains in patients receiving CS therapy, clinicians should be aware of ON. We suggest that knee joint MRI should be performed to exclude the presence of $\mathrm{ON}$ if plain radiography is unremarkable and patient still complains of knee joint pain.
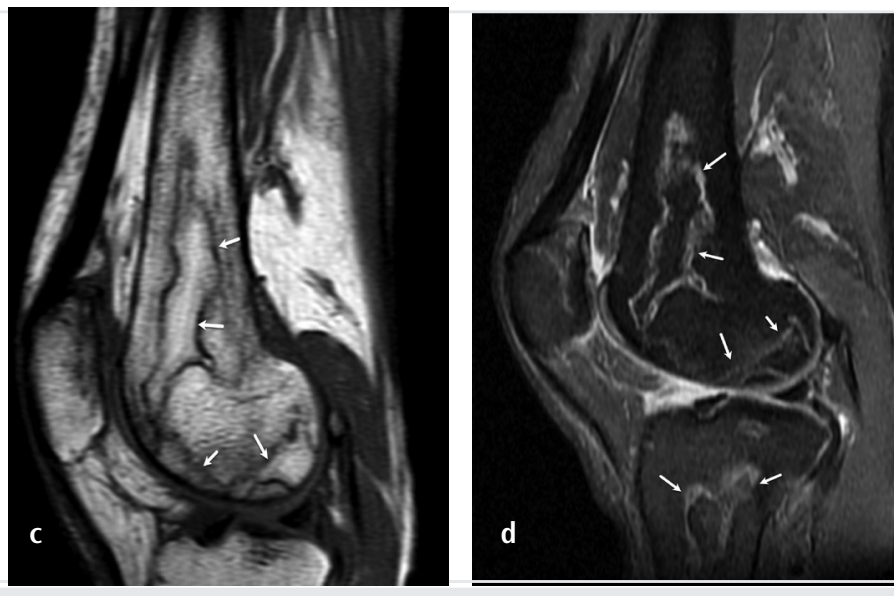

Figure 3. a-d. A 28-year-old female patient with systemic lupus erythematosus treated with corticosteroid for 7 years. Anteroposterior (a) and lateral (b) X-rays are unremarkable. Sagittal T1-Weighted (T1-W) spin-echo (c) and sagittal proton density weighted-fast spin-echo (d) images show multifocal serpiginous areas consistent with osteonecrosis that also involves the subarticular region (arrows) 


\begin{tabular}{l|l|l|}
$\begin{array}{l}\text { Table 4. The clinical indications for corticosteroid therapy in } \\
\text { patients }\end{array}$ \\
\hline Indications for corticosteroid therapy & $\begin{array}{l}\text { Number of patients (patients } \\
\text { with knee osteonecrosis) }\end{array}$ \\
\hline Lymphoma & $21(4)$ \\
\hline History of renal transplantation & $20(4)$ \\
\hline Rheumatoid arthritis & $21(3)$ \\
\hline Systemic lupus erythematosus & $10(3)$ \\
\hline Behçet's disease & $8(3)$ \\
\hline Dermatomyositis & $6(2)$ \\
\hline Retroperitoneal fibrosis & $5(2)$ \\
\hline Sarcoidosis & $11(2)$ \\
\hline Ulcerative colitis & $11(1)$ \\
\hline Ankylosing spondylitis & $11(1)$ \\
\hline Giant cell arthritis & $9(1)$ \\
\hline Sjögren's syndrome & $8(1)$ \\
\hline Pemphigus vulgaris & $4(1)$ \\
\hline
\end{tabular}

Spontaneous ON of the knee, described by Ahlbäck et al. (20), is a disorder of unknown etiology and usually affects a single location in older patients. However, CS-induced knee joint ON usually affects younger patients and presents with multiple simultaneous lesions in the femur or tibia (21). Similarly, we found multiple lesions in 31 of 37 knee joints (83.8\%) with ON.

A circumscribed subchondral "band-like" hypointense lesion on T1W images and "double-line sign" on T2W images were considered pathognomonic for femoral head ON (22). The "double-line sign" consists of a hypointense outer rim (represents the reactive bone) and a hyperintense inner rim (represents granulation tissue) on T2W images. Double-line sign was found to be present in $80 \%$ of the lesions. Similarly, we found that $75.7 \%$ of dominant lesions had double-line sign on T2W images. The presence of bone marrow edema in MRI is controversial because it has two main causes: $\mathrm{ON}$ and bone marrow edema syndrome. The distinction between these entities is very important because treatment is different. $\mathrm{ON}$ is a progressive disease requiring early diagnosis and treatment, whereas bone marrow edema syndrome resolves spontaneously and surgery is not recommended. In MRI, presence of diffuse pattern in the absence of subchondral lesions seems to almost always correspond to transient bone marrow edema syndrome, which is a self-limiting disorder $(23,24)$. In addition, the presence of bone marrow edema in patients with ON has been shown to be correlate with pain (23). In our cohort, all patients with knee joint MRI complained of pain and we found that 89.1\% of knee joints with ON showed bone marrow edema. We also found that subchondral spaces were involved in $64.9 \%$ of knee joints with $\mathrm{ON}$.

\section{Study Limitations}

One limitation of our study was the lack of histopathological diagnosis of the lesions. However, this did not significantly affect our results because MRI is the gold standard for the diagnosis of ON with a very high sensitivity and specificity. Second, due to the retrospective nature of our study, we could not determine the doses of CS taken by patients. However, many authors claim that the cumulative CS dose is the most important factor for the development of ON (4-6). Third, the number of patients is limited in our study. Therefore, there is a need for prospective studies with larger number of patients. Finally, all patients in our study had complaints of joint pain, thus there was a lack of pain-free patients receiving CS therapy.

\section{Conclusion}

Thirty-one point three percent of patients with knee joint ON with arthralgia who were receiving CS therapy had ON of the hip joint. Regarding its high specificity and easy accessibility, plain radiography should be the first choice in knee joint pain in patients on CS therapy. Despite a normal plain radiography, MRI should be performed in patients whose complaints are not resolved. There were multiple lesions in MRI in most of the patients who had CS-induced knee joint ON. Double-line sign and bone marrow edema were the most common MRI findings in CS-induced ON of the knee.

Ethics Committee Approval: This study was approved by institutional Pamukkale Universtiy Ethics Committee (decision no: 60116787 020/8340).

Informed Consent: Informed consent was waived due to retrospective nature of the study.

Peer-review: Externally and internally peer-reviewed.

Author Contributions: Concept - N.S.; Design - N.S.; Data Collection and/ or Processing -N.S., F.U.; Analysis and/or Interpretation - F.U.; Literature Search - F.U.; Writing Manuscript - N.S., F.U.

Conflict of Interest: No conflict of interest was declared by the authors.

Financial Disclosure: The authors declared that this study received no financial support.

\section{References}

1. Shah KN, Racine J, Jones LC, Aaron RK. Pathophysiology and risk factors for osteonecrosis. Curr Rev Musculoskelet Med 2015; 8: 201-9.

2. Moya-Angeler J, Gianakos AL, Villa JC, Ni A, Lane JM. Current concepts on osteonecrosis of the femoral head. World J Orthop 2015; 6: 590-601.

3. Mont MA, Marker DR, Zywiel MG, Carrino JA. Osteonecrosis of the knee and related conditions. J Am Acad Orthop Surg 2011; 19: 482-94.

4. Shigemura T, Nakamura J, Kishida S, Harada Y, Ohtori S, Kamikawa K, et al. Incidence of osteonecrosis associated with corticosteroid therapy among different underlying diseases: prospective MRI study. Rheumatology (Oxford) 2011; 50: 2023-8.

5. Zhang NF, Li ZR, Wei HY, Liu ZH, Hernigou P. Steroid-induced osteonecrosis the number of lesions is related to the dosage. J Bone Joint Surg Br 2008; 90: 1239 - 43.

6. Bradbury G, Benjamin J, Thompson J, Kiees E, Copeland J. Avascular necrosis of bone after cardiac transplantation. Prevalence and relationship to administration and dosage or steroids. J Bone Joint Surg Am 1994; 76: 1385-8.

7. Vreden SG, Hermus AR, van Liessum PA, Pieters GF, Smals AG, Kloppenborg PW. Aseptic bone necrosis in patients on glucocorticoid replacement therapy. Neth J Med 1991; 39: 153-7. 
8. Drescher W, Schlieper G, Floege J, Eitner F. Steroid-related osteonecrosis-an update. Nephrology Dialysis Transplantation 2011; 26: 2728-31.

9. Chan KL, Mok CC. Glucocorticoid-induced avascular bone necrosis: diagnosis and management. Open Orthop J 2012; 6: 449-57.

10. Murphey MD, Foreman KL, Klassen-Fischer MK, Fox MG, Chung EM, Kransdorf MJ. From the radiologic pathology archives imaging of osteonecrosis: radiologic-pathologic correlation. Radiographics 2014; 34: 1003-28.

11. Zalavras CG, Lieberman JR. Osteonecrosis of the femoral head: evaluation and treatment. J Am Acad Orthop Surg 2014; 22: 455-64.

12. Karantanas AH. Accuracy and limitations of diagnostic methods for avascular necrosis of the hip. Expert Opin Med Diagn 2013; 7: 179-87.

13. Malizos KN, Karantanas AH, Varitimidis SE, Dailiana ZH, Bargiotas K, Maris T. Osteonecrosis of the femoral head: etiology, imaging and treatment. Eur J Radiol 2007; 63: 16-28.

14. Pierce TP, Jauregui JJ, Cherian JJ, Elmallah RK, Mont MA. Imaging evaluation of patients with osteonecrosis of the femoral head. Curr Rev Musculoskelet Med 2015; 8: 221-7.

15. Lee GC, Khoury V, Steinberg D, Kim W, Dalinka M, Steinberg M. How do radiologists evaluate osteonecrosis? Skeletal Radiol 2014; 43: 607-14.

16. Conklin JJ, Alderson PO, Zizic TM, Hungerford DS, Densereaux JY, Gober A, Wagner HN. Comparison of bone scan and radiograph sensitivity in the detection of steroid-induced ischemic necrosis of bone. Radiology 1983; 147: 221-6.
17. Deutsch SD, Gandsman EJ, Spraragen SC. Quantitative regional blood-flow analysis and its clinical application during routine bone-scanning. J Bone Joint Surg Am 1981; 63: 295-305.

18. Oh SN, Jee WH, Cho SM, Kim SH, Kang HS, Ryu KN, et al. Osteonecrosis in patients with systemic lupus erythematosus: MR imaging and scintigraphic evaluation. Clin Imaging 2004; 28: 305-9.

19. Hussein S, Suitner M, Béland-Bonenfant S, Baril-Dionne A, Vandermeer B, Santesso N, et al. Monitoring of osteonecrosis in systemic lupus erythematosus: A systematic review and metaanalysis. J Rheumatol 2018; 45: 1462-76.

20. Ahlbäck S, Bauer GC, Bohne WH. Spontaneous osteonecrosis of the knee. Arthritis Rheum 1968; 11: 705-33.

21. Zywiel MG, McGrath MS, Seyler TM, Marker DR, Bonutti PM, Mont MA Osteonecrosis of the knee: a review of three disorders. Orthop Clin North Am 2009; 40: 193-211.

22. Gorbachova T, Melenevsky Y, Cohen M, Cerniglia BW. Osteochondral lesions of the knee: differentiating the most common entities at MRI. Radiographics 2018; 38: 1478-95

23. Sonoda K, Motomura G, Kawanami S, Takayama Y, Honda H, Yamamoto T, et al. Degeneration of articular cartilage in osteonecrosis of the femoral head begins at the necrotic region after collapse: a preliminary study using T1 rho MRI. Skeletal Radiol 2017; 46: 463-7.

24. Geith T, Niethammer T, Milz S, Dietrich O, Reiser M, Baur-Melnyk A. Transient bone marrow edema syndrome versus osteonecrosis: perfusion patterns at dynamic contrast-enhanced MR imaging with high temporal resolution can allow differentiation. Radiology 2017; 283: 478-85. 